\title{
Bacillus niabensis sp. nov., isolated from cotton-waste composts for mushroom cultivation
}

Correspondence

Byung-Yong Kim

kimby@rda.go.kr

\author{
Soon-Wo Kwon, ${ }^{1}$ Seon-Young Lee, ${ }^{1}$ Byung-Yong Kim, \\ Hang-Yeon Weon, ${ }^{2}$ Jung-Bong Kim, ${ }^{1}$ Seung-Joo Go ${ }^{1}$ and Gil-Bok Lee ${ }^{1}$
}

\author{
${ }^{1}$ Korean Agricultural Culture Collection (KACC), Microbial Genetics Division, National Institute of \\ Agricultural Biotechnology, Rural Development Administration, Suwon 441-707, Republic of Korea \\ ${ }^{2}$ Applied Microbiology Division, National Institute of Agricultural Science and Technology, Rural \\ Development Administration, Suwon 441-707, Republic of Korea
}

\begin{abstract}
A group of five bacilli, designated strains $4 \mathrm{~T} 12,4 \mathrm{~T}_{19}{ }^{\top}, 5 \mathrm{M} 45,5 \mathrm{M} 53$ and $5 \mathrm{~T} 52$, isolated from cotton-waste composts for mushroom cultivation, were examined. These strains were Gram-positive, aerobic, motile, spore-forming rods. 16S rRNA gene sequence analyses revealed that the isolates belonged to the genus Bacillus, showing the highest levels of similarity (approx. 96.6-96.9\%) with respect to Bacillus herbersteinensis DSM 16534 ${ }^{\top}$. The values for DNA-DNA hybridization (approx. 85-96\%) among these five strains revealed that they belong to the same species. The major menaquinone present was MK-7 and the predominant cellular fatty acids were anteiso- $\mathrm{C}_{15: 0}$ (approx. 24.5-33.9\%) and $\mathrm{C}_{16: 0}$ (approx. 15.1-34.1\%). The DNA G + C contents were 37.7-40.9 mol\%. On the basis of physiological, biochemical, chemotaxonomic and comparative genomic analyses, the five isolates represent a novel species of the genus Bacillus, for which the name Bacillus niabensis sp. nov. is proposed. The type strain is $4 \mathrm{~T} 19^{\top}\left(=\operatorname{KACC} 11279^{\top}=\mathrm{DSM} 17723^{\top}\right)$.
\end{abstract}

Cotton waste is frequently used in Korea as a medium for the cultivation of oyster mushrooms. In the course of a study of the changes in microbial communities involved in the composting of cotton wastes, the temperature of the material was raised gradually from room temperature to $65{ }^{\circ} \mathrm{C}$, and five bacterial strains were isolated.

Samples were spread on tryptic soy agar (TSA; Difco) at $\mathrm{pH} 7.0$ and incubated at $30{ }^{\circ} \mathrm{C}$ for 3 days. Light-yellow colonies were produced on TSA and nutrient agar (Difco). Gram staining was performed with a Gram-stain kit (Difco) according to the manufacturer's protocol. A $\mathrm{KOH}$ test and an L-alanine aminopeptidase assay were also performed (Gregersen, 1978). The cell morphology was observed by using transmission electron microscopy (model 912AB; LEO) and phase-contrast microscopy (AXIO; Zeiss) after cultivation on TSA for 2 days.

Various physiological tests were carried out according to Gordon et al. (1973) and Claus \& Berkeley (1986). The

The GenBank/EMBL/DDBJ accession numbers for the 16S rRNA gene sequences of strains $4 \mathrm{~T} 12,4 \mathrm{~T} 19^{\top}, 5 \mathrm{M} 45,5 \mathrm{M} 53$ and $5 \mathrm{~T} 52$ are DQ176420, AY998119, DQ176421, DQ176422 and DQ176423, respectively.

Phase-contrast micrographs of the novel strains and tables showing their phenotypic characteristics and fatty acid compositions and levels of DNA-DNA hybridization between the novel isolates are available as supplementary material with the online version of this paper.
Voges-Proskauer test was performed along with tests for catalase activity, temperature ranges for growth (from 5 to $65{ }^{\circ} \mathrm{C}$, using $5{ }^{\circ} \mathrm{C}$ increments), resistance to lysozyme $(0.001 \%)$, growth in the presence of $\mathrm{NaCl}$ (at $0,3,5,7,10$ and $15 \%), \mathrm{pH}$ range for growth $(\mathrm{pH} 4-9$ in increments of $1.0 \mathrm{pH}$ unit), acid production from carbohydrates (Dglucose, L-arabinose, D-xylose and D-mannitol), gas formation from glucose, utilization of citrate and propionate, production of indole and dihydroxyacetone, deamination of phenylalanine, decomposition of casein and tyrosine and liquefaction of gelatin. The oxidase test and tests for the hydrolysis of aesculin, gelatin and starch were conducted according to Smibert \& Krieg (1994). Motility tests were performed on motility medium, which was composed of $0.1 \%$ yeast extract, $0.01 \% \quad \mathrm{~K}_{2} \mathrm{HPO}_{4}$ and $0.2 \%$ agar. Anaerobic growth was tested in serum bottles by adding thioglycolate $\left(1 \mathrm{~g} \mathrm{l}^{-1}\right)$ to tryptic soy broth medium and replacing the upper airspace with nitrogen gas. To test for the reduction of nitrate and nitrite, each isolate was inoculated into three serum bottles $(25 \mathrm{ml})$ containing tryptic soy broth medium, while nitrate and nitrite were added as $\mathrm{KNO}_{3}$ and $\mathrm{NaNO}_{2}$ at concentrations of $10 \mathrm{mM}$. The reduction of nitrate and nitrite was monitored using an ion chromatograph (model 790 personal IC; Metrohm) equipped with a conductivity detector and an anion-exchange column (Metrosep Anion Supp 4; Metrohm). The urease test was performed according to Kim et al. (2006). 
The 16S rRNA gene of each isolate was amplified by means of a PCR with two universal primers, as described previously (Kwon et al., 2003). The sequences of amplified $16 \mathrm{~S}$ rRNA genes were analysed using a DNA sequencer (ABI3100; Applied Biosystems). The 16S rRNA gene sequences were aligned using CLUSTAL $W$ software (Thompson et al., 1994). Nucleotide similarity values were calculated from the alignment. An evolutionary distance matrix was constructed using a two-parameter model (Kimura, 1980), and phylogenetic trees for the datasets were inferred with the neighbour-joining method (Saitou \& Nei, 1987) using MEGA, version 3.0 (Kumar et al., 2004). The stability of relationships was assessed by performing bootstrap analyses of the neighbour-joining data (based on 1000 resamplings).

DNA-DNA hybridization was carried out using the filter hybridization method described by Seldin \& Dubnau (1985). Probe labelling was conducted by using the nonradioactive DIG-High prime system (Roche), and hybridized DNA was visualized using a DIG luminescent detection kit (Roche). DNA-DNA relatedness was quantified by using a densitometer (Bio-Rad). Chemotaxonomic characteristics of these strains in this study were determined using cells grown at $30{ }^{\circ} \mathrm{C}$ on TSA for $24 \mathrm{~h}$. Isoprenoid quinones were analysed by HPLC (Shimadzu) as described previously (Groth et al., 1996). DNA G+C contents $(\mathrm{mol} \%)$ were determined by performing HPLC analysis of deoxyribonucleosides, as described by Mesbah et al. (1989). Analysis of the fatty acid methyl esters was performed by GLC according to the instructions for the Microbial Identification System (MIDI).

The five strains, $4 \mathrm{~T} 19^{\mathrm{T}}$, 4T12, 5M45, 5M53 and 5T52, showed similar morphologies. The cells were rod-shaped, occurring singly or in filamentous chains. Single cells were $0.5-0.7 \mu \mathrm{m}$ in diameter and $2.0-3.0 \mu \mathrm{m}$ in length. Spores were ellipsoidal or oval, occurring subterminally or terminally in swollen sporangia (see Supplementary Fig. S1 in IJSEM Online).

The isolates were motile on the medium used in this study. The growth temperature range for the isolates was 15$40{ }^{\circ} \mathrm{C}$ and the $\mathrm{pH}$ range for growth was $\mathrm{pH} 6.0-8.0$ (optimum, pH 7.0), these ranges being different from those for Bacillus litoralis and Bacillus herbersteinensis. The isolates differed from each other with regard to growth ranges for $\mathrm{NaCl}(\%)$ : strain $4 \mathrm{~T} 19^{\mathrm{T}}$ grew in the presence of $\mathrm{NaCl}(\mathrm{w} / \mathrm{v})$ at concentrations up to $5 \%, 4 \mathrm{~T} 12$ could grow with $\mathrm{NaCl}$ concentrations up to only $3 \%$ and the other isolates did not grow in the presence of $3 \% \mathrm{NaCl}$. All isolates were positive for catalase, urease, nitrate reduction, acid production from D-glucose, L-arabinose, D-xylose and D-mannitol and hydrolysis of aesculin, gelatin and starch. All isolates were negative for oxidase, phenylalanine deamination, the formation of indole and dihydroxyacetone, in the Voges-Proskauer test and for the utilization of citrate and propionate. Detailed results of the physiological characterizations are given in the species description, and features that serve to distinguish between the isolates and related Bacillus species are listed in Table 1 and in Supplementary Table S1 (available in IJSEM Online).

For the phylogenetic analysis of the 16S rRNA gene sequences, representative sequences retrieved from GenBank were aligned from position $37\left(5^{\prime}\right)$ to position 1330 (3') (Escherichia coli numbering; Brosius et al., 1978). All of the isolates, which fell within the radiation of the genus Bacillus including Bacillus subtilis, formed a compact cluster with $100 \%$ bootstrap support (Fig. 1). The $16 \mathrm{~S}$ rRNA gene sequence similarity between strain $4 \mathrm{~T} 19^{\mathrm{T}}$ and the other isolates was approximately $99.5-99.7 \%$. However, strain $4 \mathrm{~T} 19^{\mathrm{T}}$ exhibited relatively low levels of $16 \mathrm{~S}$ rRNA gene sequence similarity with respect to Bacillus species. The closest relatives of strain $4 \mathrm{~T} 19^{\mathrm{T}}$ were the type strains of B. herbersteinensis $(96.7 \%)$, B. litoralis $(96.2 \%)$ and Bacillus cohnii (96.0\%).

DNA-DNA hybridization was performed to determine the genetic relatedness between all five isolates. The DNADNA relatedness value between strain $4 \mathrm{~T} 19^{\mathrm{T}}$ and the other isolates was 91-96\%, meaning that they represent the same species (Wayne et al., 1987) (Supplementary Table S2). Meanwhile, the low levels of 16S rRNA gene sequence similarity $(<97 \%)$ between $4 \mathrm{~T} 19^{\mathrm{T}}$ and the type strains of Bacillus species with validly published names confirm that this strain represents a species that is distinct from recognized Bacillus species (Stackebrandt \& Goebel, 1994).

Fatty acid analysis revealed some differences between the isolates and related Bacillus species (Table 1). The major fatty acid components of the isolates were anteiso- $\mathrm{C}_{15: 0}$, $\mathrm{C}_{16: 0}$, anteiso- $\mathrm{C}_{17: 0}$, iso- $\mathrm{C}_{16: 0}$ and iso- $\mathrm{C}_{14: 0}$ (Supplementary Table S3). The isolates contained an unsaturated menaquinone with seven isoprene units (MK-7) as the predominant isoprenoid quinone. The $\mathrm{G}+\mathrm{C}$ contents of the isolates were in the range $37.7-40.9 \mathrm{~mol} \%$, which is higher than the values for $B$. litoralis, $B$. herbersteinensis, $B$. cohnii and Bacillus fastidiosus.

On the basis of the polyphasic data, the five isolates represent a novel species of the genus Bacillus, for which the name Bacillus niabensis sp. nov. is proposed.

\section{Description of Bacillus niabensis sp. nov.}

Bacillus niabensis (niab.en'sis. N.L. masc. adj. niabensis arbitrary name formed from NIAB, the acronym for the National Institute of Agricultural Biotechnology, Korea, where taxonomic studies on this species were performed).

Cells are Gram-positive, motile, spore-forming rods, 0.5$0.7 \times 2.0-3.0 \mu \mathrm{m}$, motile by means of single polar flagella. Cells form ellipsoidal or oval spores that occur subterminally or terminally in swollen sporangia. Colonies are yellowish white, 2-3 $\mathrm{mm}$ in diameter and circular with clear margins after incubation on TSA for 2 days. Growth occurs at temperatures ranging from 15 to $50{ }^{\circ} \mathrm{C}$, the optimum being $30^{\circ} \mathrm{C}$. Growth occurs at $\mathrm{pH} 6.0-8.0$, the optimum being $\mathrm{pH}$ 7.0. Capable of growing anaerobically. 
Table 1. Characteristics that serve to differentiate the novel strains from recognized Bacillus species

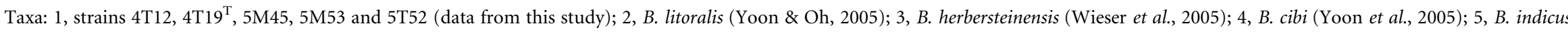

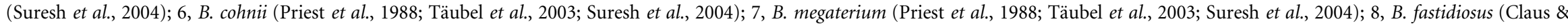

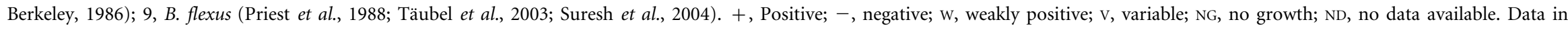
parentheses are for the type strain. The cells of all taxa listed are rod-shaped and catalase-positive.

\begin{tabular}{|c|c|c|c|c|c|c|c|c|c|}
\hline Characteristic & 1 & 2 & 3 & 4 & 5 & 6 & 7 & 8 & 9 \\
\hline Spore position ${ }^{\star}$ & $\mathrm{S}, \mathrm{T}$ & $\mathrm{C}, \mathrm{S}$ or $\mathrm{T}$ & $\mathrm{T}$ & $\mathrm{C}$ or $\mathrm{s}$ & s & $\mathrm{T}$ & C & $\mathrm{ND}$ & $\mathrm{ND}$ \\
\hline Spore shape $\dagger$ & $\mathrm{E}$ & $\mathrm{E}$ & $\mathrm{ND}$ & $\mathrm{E}$ & $\mathrm{ND}$ & $\mathrm{E}$ & $\mathrm{E}$ & $\mathrm{E}$ & ND \\
\hline Sporangium shape & Swollen & Swollen & Not swollen & Swollen & Slightly swollen & Swollen & Swollen & Not swollen & $\mathrm{ND}$ \\
\hline Oxidase activity & - & + & + & + & $\mathrm{ND}$ & + & - & ND & ND \\
\hline Anaerobic growth & + & - & ND & - & - & ND & - & - & ND \\
\hline $\mathrm{pH}$ range & $6-8$ & $5.5-7.5$ & $7-12$ & $5.5-7.5$ & $6-7$ & 5 & $4.5-9.5$ & $\mathrm{ND}$ & $4.5-9.5$ \\
\hline Optimum $\mathrm{pH}$ & 7 & 7.5 & $8-9$ & $6.5-7.5$ & 7 & 9 & 7 & ND & 7 \\
\hline $\mathrm{NaCl}(\%)$ range & $(0-5)$ & $2-10$ & $0-5$ & $0-12$ & $0-2$ & $0-10(\mathrm{w})$ & $0-5$ & $0-5$ & $0-10(w)$ \\
\hline Temperature $\left({ }^{\circ} \mathrm{C}\right)$ range & $15-50$ & $4-45$ & $4-28$ & $10-40$ & $15-37$ & $10-47$ & $10-40$ & $10-40$ & $17-40$ \\
\hline \multicolumn{10}{|l|}{ Acid from: } \\
\hline L-Arabinose & + & + & - & - & $\mathrm{ND}$ & ND & $\mathrm{v}$ & NG & ND \\
\hline D-Glucose & + & + & - & + & - & $(-)$ & + & NG & + \\
\hline D-Mannitol & + & - & - & - & - & $(-)$ & $\mathrm{v}$ & NG & + \\
\hline D-Xylose & + & + & - & - & - & $(-)$ & $\mathrm{V}$ & NG & - \\
\hline \multicolumn{10}{|l|}{ Hydrolysis of: } \\
\hline Aesculin & + & + & $\mathrm{ND}$ & + & + & $(-)$ & + & $\mathrm{ND}$ & - \\
\hline Casein & - & + & $\mathrm{ND}$ & + & $\mathrm{ND}$ & $\mathrm{v}(+)$ & + & - & ND \\
\hline Gelatin & + & + & ND & - & + & + & + & - & - \\
\hline Starch & + & + & + & + & ND & + & + & - & + \\
\hline Nitrate reduction & + & - & - & - & - & + & - & - & - \\
\hline Urease activity & + & + & ND & - & - & - & + & ND & - \\
\hline DNA G $+\mathrm{C}$ content $(\mathrm{mol} \%)$ & $37.7-40.8$ & 35.2 & $36.2-36.9$ & 45 & 41.2 & $33.9-35.0$ & $37.3-37.6$ & $34.3-35.1$ & 38.4 \\
\hline Major fatty acid(s) & ai- $C_{15: 0}, C_{16: 0}$ & $\begin{array}{c}\text { ai- } C_{15: 0} \\
\text { i- } C_{15: 0}\end{array}$ & $\begin{array}{l}\text { ai- } C_{15: 0} \\
\text { i- } C_{15: 0}\end{array}$ & $\begin{array}{l}\mathrm{i}-\mathrm{C}_{15: 0} \\
\mathrm{i}-\mathrm{C}_{14: 0}\end{array}$ & $\begin{array}{l}\mathrm{i}-\mathrm{C}_{15: 0} \\
\text { ai- } \mathrm{C}_{15: 0}\end{array}$ & $\begin{array}{c}\text { ai- } C_{17: 0}, i-C_{15: 0} \\
\text { ai- } C_{15: 0} \text { or } i-C_{15: 0} \\
\text { ai- } C_{15: 0}\end{array}$ & ai- $\mathrm{C}_{15: 0}$ & $\mathrm{ND}$ & $\begin{array}{l}\text { ai- } C_{15: 0} \\
\text { i- } C_{15: 0}\end{array}$ \\
\hline
\end{tabular}

${ }^{*} \mathrm{C}$, Central or paracentral; s, subterminal; $\mathrm{T}$, terminal.

$\dagger$, Ellipsoidal or oval. 


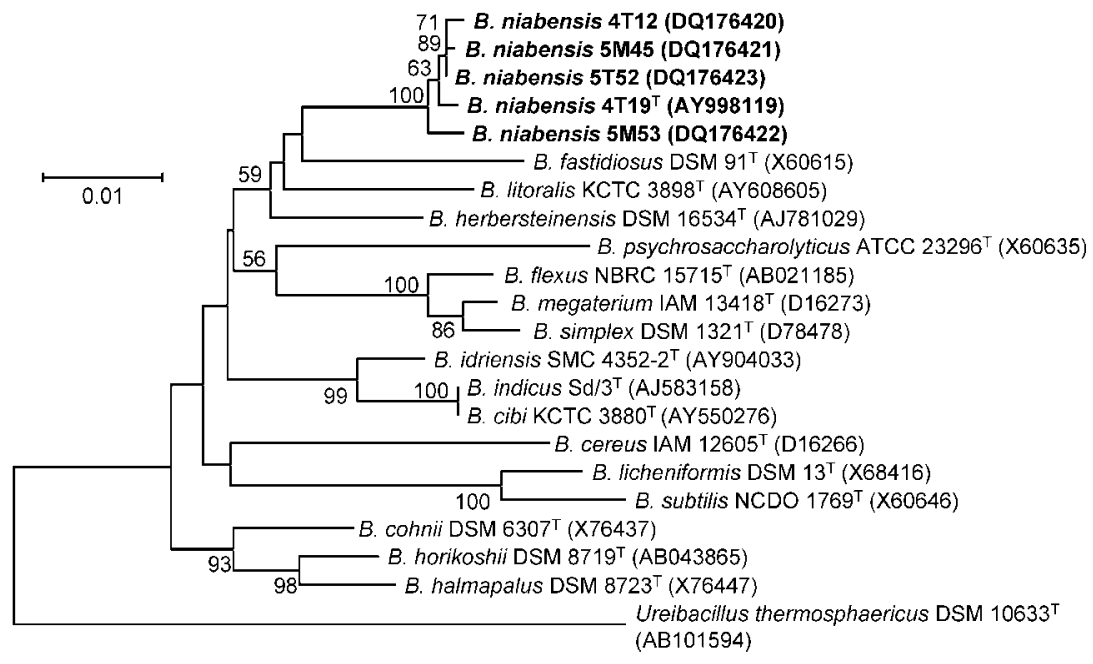

Fig. 1. Neighbour-joining phylogenetic tree, based on 16S rRNA gene sequences, showing the position of the novel strains in relation to selected Bacillus species. Bootstrap values (expressed as percentages of 1000 replications) greater than $50 \%$ are shown at branch points. Bar, 0.01 substitutions per nucleotide position.
$\mathrm{NaCl}$ growth range is variable, being in the range $0-5 \%$ $(\mathrm{w} / \mathrm{v})$. Positive for catalase, urease, acid production from D-glucose, L-arabinose, D-xylose and D-mannitol and hydrolysis of aesculin, gelatin and starch. Negative for oxidase, formation of indole and dihydroxyacetone, phenylalanine deamination, utilization of citrate and propionate, degradation of tyrosine, growth with lysozyme and in the Voges-Proskauer test. Nitrate is reduced under anaerobic conditions. The major cellular fatty acids are anteiso- $\mathrm{C}_{15: 0}, \mathrm{C}_{16: 0}$, anteiso- $\mathrm{C}_{17: 0}$ and iso- $\mathrm{C}_{16: 0}$. The major quinone is MK-7. The DNA G+C contents are 37.7-40.9 mol\%, as determined by HPLC.

The type strain, $4 \mathrm{~T} 19^{\mathrm{T}}\left(=\right.$ KACC $\left.11279^{\mathrm{T}}=\mathrm{DSM} 17723^{\mathrm{T}}\right)$, was isolated from cotton-waste composts in Suwon, Korea.

\section{Acknowledgements}

We are grateful to two anonymous reviewers for meticulous reading of earlier versions of the manuscript. This study was supported by the National Institute of Agricultural Biotechnology (NIAB, grant no. 064-11-19-1), Rural Development Administration, Republic of Korea.

\section{References}

Brosius, J., Palmer, M. L., Kennedy, P. J. \& Noller, H. F. (1978). Complete nucleotide sequence of a $16 \mathrm{~S}$ ribosomal RNA gene from Escherichia coli. Proc Natl Acad Sci U S A 75, 4801-4805.

Claus, D. \& Berkeley, R. C. W. (1986). Genus Bacillus Cohn 1872. In Bergey's Manual of Systematic Bacteriology, vol. 2, pp. 1105-1140. Edited by P. H. A. Sneath, N. S. Mair, M. E. Sharpe \& J. G. Holt. Baltimore: Williams \& Wilkins.

Gordon, R. E., Haynes, W. C. \& Pang, C. H.-N. (1973). The Genus Bacillus. US Department of Agriculture Handbook no. 427. Washington, DC: US Department of Agriculture.

Gregersen, T. (1978). Rapid method for distinction of Gram-negative from Gram-positive bacteria. Eur J Appl Microbiol Biotechnol 5, 123-127.

Groth, I., Schumann, P., Weiss, N., Martin, K. \& Rainey, F. A. (1996). Agrococcus jenensis gen. nov., sp. nov., a new genus of actinomycetes with diaminobutyric acid in the cell wall. Int J Syst Bacteriol 46, 234-239.
Kim, B. Y., Lee, S. Y., Weon, H. Y., Kwon, S. W., Go, S. J., Park, Y. K., Schumann, P. \& Fritze, D. (2006). Ureibacillus suwonensis sp. nov., isolated from cotton waste composts. Int J Syst Evol Microbiol 56, 663-666.

Kimura, M. (1980). A simple method for estimating evolutionary rates of base substitutions through comparative studies of nucleotide sequences. J Mol Evol 16, 111-120.

Kumar, S., Tamura, K. \& Nei, M. (2004). MEGA3: integrated software for molecular evolutionary genetics analysis and sequence alignment. Brief Bioinform 5, 150-163.

Kwon, S. W., Kim, J. S., Park, I. C., Yoon, S. H., Park, D. H., Lim, C. K. \& Go, S. J. (2003). Pseudomonas koreensis sp. nov., Pseudomonas umsongensis sp. nov. and Pseudomonas jinjuensis sp. nov., novel species from farm soils in Korea. Int J Syst Evol Microbiol 53, 21-27.

Mesbah, M., Premachandran, U. \& Whitman, W. B. (1989). Precise measurement of the $\mathrm{G}+\mathrm{C}$ content of deoxyribonucleic acid by high-performance liquid chromatography. Int J Syst Bacteriol 39, 159-167.

Priest, F. G., Goodfellow, M. \& Todd, C. (1988). A numerical classification of the genus Bacillus. J Gen Microbiol 134, 1847-1882.

Saitou, N. \& Nei, M. (1987). The neighbor-joining method: a new method for reconstructing phylogenetic trees. Mol Biol Evol 4, 406-425.

Seldin, L. \& Dubnau, D. (1985). DNA homology among Bacillus polymyxa, Bacillus macerans, Bacillus azotofixans, and other nitrogenfixing Bacillus strains. Int J Syst Bacteriol 35, 151-154.

Smibert, R. M. \& Krieg, N. R. (1994). Phenotypic characterization. In Methods for General and Molecular Bacteriology, pp. 607-654. Edited by P. Gerhardt, R. G. E. Murray, W. A. Wood \& N. R. Krieg. Washington, DC: American Society for Microbiology.

Spanka, R. \& Fritze, D. (1993). Bacillus cohnii sp. nov., a new, obligately alkaliphilic, oval-spore-forming Bacillus species with ornithine and aspartic acid instead of diaminopimelic acid in the cell wall. Int J Syst Bacteriol 43, 150-156.

Stackebrandt, E. \& Goebel, B. M. (1994). Taxonomic note: a place for DNA-DNA reassociation and 16S rRNA sequence analysis in the present species definition in bacteriology. Int J Syst Bacteriol 44, 846-849.

Suresh, K., Prabagaran, S. R., Sengupta, S. \& Shivaji, S. (2004). Bacillus indicus sp. nov., an arsenic-resistant bacterium isolated from an aquifer in West Bengal, India. Int J Syst Evol Microbiol 54, 1369-1375. 
Täubel, M., Kämpfer, P., Buczolits, S., Lubitz, W. \& Busse, H.-J. (2003). Bacillus barbaricus sp. nov., isolated from an experimental wall painting. Int J Syst Evol Microbiol 53, 725-730.

Thompson, J. D., Higgins, D. G. \& Gibson, T. J. (1994). CLUSTAL W: improving the sensitivity of progressive multiple sequence alignment through sequence weighting, position-specific gap penalties and weight matrix choice. Nucleic Acids Res 22, 4673-4680.

Wayne, L. G., Brenner, D. J., Colwell, R. R., Grimont, P. A. D., Kandler, O., Krichevsky, M. I., Moore, L. H., Moore, W. E. C., Murray, R. G. E. \& other authors (1987). International Committee on Systematic
Bacteriology. Report of the ad hoc committee on reconciliation of approaches to bacterial systematics. Int J Syst Bacteriol 37, 463-464.

Wieser, M., Worliczek, H., Kämpfer, P. \& Busse, H.-J. (2005). Bacillus herbersteinensis sp. nov. Int J Syst Evol Microbiol 55, 2119-2123.

Yoon, J.-H. \& Oh, T.-K. (2005). Bacillus litoralis sp. nov., isolated from a tidal flat of the Yellow Sea in Korea. Int J Syst Evol Microbiol 55, 1945-1948.

Yoon, J.-H., Lee, C.-H. \& Oh, T.-K. (2005). Bacillus cibi sp. nov., isolated from jeotgal, a traditional Korean fermented seafood. Int $J$ Syst Evol Microbiol 55, 733-736. 